\title{
Familial supernumerary nipples
}

INSERM

\section{Source}

INSERM. (1999). Orphanet: an online rare disease and orphan drug data base. Familial supernumerary nipples. ORPHA:2456

Familial supernumerary nipples is a rare breast malformation characterized by the presence, in various members of a single family, of one or more nipple(s) and/or their related tissue, in addition to the normal bilateral chest nipples. The anomaly is usually situated along the embryonic milk line, from axillae to inguinal regions, but other locations are also possible. Association with dental abnormalities, Becker nevus, renal or underlying breast tissue malignancy and genitourinary malformations has been reported. 